\title{
Chapter 30 \\ Article 19: The Right to Protection from All Forms of Violence
}

\author{
Christian Whalen
}

\section{Article 19}

1. States Parties shall take all appropriate legislative, administrative, social and educational measures to protect the child from all forms of physical or mental violence, injury or abuse, neglect or negligent treatment, maltreatment or exploitation, including sexual abuse, while in the care of parent(s), legal guardian(s) or any other person who has the care of the child.

2. Such protective measures should, as appropriate, include effective procedures for the establishment of social programmes to provide necessary support for the child and for those who have the care of the child, as well as for other forms of prevention and for identification, reporting, referral, investigation, treatment and follow-up of instances of child maltreatment described heretofore, and, as appropriate, for judicial involvement.

C. Whalen (西)

Office of the Child and Youth Advocate, Fredericton, NB, Canada

e-mail: Christian.Whalen@gnb.ca 


\section{What Did Children Say?}

'There are laws prohibiting violence.' (Eastern Europe)

'It is important to have training on how to be good parents (parenthood) and that this training be extended to the whole community because all people in the community are responsible for the education of children.' (Western Europel Other)

The state must make an annual report on child rights violations. (Africa) 'Policies to stop children from physical punishment should be introduced.' (Africa)

\section{Overview}

Article 19 is the core provision in the Convention in relation to efforts to address and eliminate all forms of harm to children (UN Committee on the Rights of the Child, 2011, para. 7 (a)). As a principle, it is closely linked to the child's right to life and maximum survival and development and informs the many protection rights set out in the Convention. However, it also is linked to many of the child's provision and participation rights, such as those touching upon abolishing harmful traditional practices, or protecting children from harmful information, while introducing the child's rights in relation to alternative family care settings when removed from their parents' care. ${ }^{1}$

It asserts, as a broad principle, the child's right to be free from all forms of harm, well beyond Article 37 and the comparable human rights standard of protection from cruel or unusual punishment afforded adults in other global human rights instruments (UNICEF, 2007, p. 249). It includes a specific requirement to protect children in the care of their parents, guardians, or any person who has care of the child.

Violence is broadly defined to include all forms of harm (UN Committee on the Rights of the Child, 2011, para. 4), and encompasses mental violence, sexual and other forms of exploitation, as well as non-intentional forms of harm, such as neglect. The Committee has been careful to guard against restrictive interpretations of the term violence. The World Health Organization has a similarly expansive interpretation of the term (UN Committee on the Rights of the Child, 2011, para. 4). ${ }^{2}$ As such, Article 19 articulates full respect for the human dignity and physical and personal integrity of children as rights-bearing individuals. The Committee stresses that this requires a paradigm shift of caregiving and protection away from the perception of children primarily as victims (2011, para. 3 (b)). Article 19 does not

\footnotetext{
${ }^{1}$ Convention Articles 20, 21, 22, and 25.

${ }^{2}$ WHO defines violence to children to include 'the intentional use of physical force or power, threatened or actual, against a child, by an individual or group that either results in or has a high likelihood of resulting in an actual or potential harm to the child's health, survival, development or dignity' (Krug et al., 2002, p. 5).
} 
have any direct precedent in global human rights treaties, as they did not specifically address concerns in relation to violence to children (Vučković-Šahović et al., 2012, p. 185).

Following the publication of the 1996 Report on the Impact of Armed Conflict on Children (Machel, 1996), the United Nations developed and ratified two additional protocols to the Convention, the Optional Protocol on the Involvement of Children in Armed Conflict (A/RES/54/263) and the Optional Protocol on the sale of children, child prostitution and child pornography (A/RES/54/263), that further extend the protections of Article 19. In addition, General Comment No. 13 (2011), The right of the child to freedom from all forms of violence, the 2006 World Report on Violence Against Children (Pinheiro, 2006), and the 2015 Global Survey on Violence Against Children (UN Special Representative of the Secretary-General on Violence against Children, 2015) constitute key reference documents in understanding the scope and purpose of Article 19.

\section{General Principles}

Article 2 While children of marginalised sectors of the population may in principle be at no greater risk of harm within their own families than others, the marginalisation of these families by society as a whole may expose them to greater risks of harm, both at home and from public sector service providers. Disabled children, for example, are at significantly greater risk of sexual harm than their ablebodied peers (UN Committee on the Rights of the Child, 2007a, para. 42). Children in early childhood, children affected by HIV/AIDS, indigenous children, and unaccompanied or separated children are also particularly at risk and the Committee has frequently underlined the importance of special measures of protection for these populations (2003a, paras. $37,38,2005$, paras. 50-53, 2006, para. 36, 2009, paras. $22,64-65,70,72)$.

The gender dimensions of violence must also be considered by States Parties in developing and implementing violence prevention strategies (UN Committee on the Rights of the Child, 2011, paras. 19, 72 (b)). An intersectional analysis of children in such populations reveals that the discriminatory impacts experienced by children with a double or triple disadvantage are among the most vulnerable (Ravnbøl, 2009). The solutions to ensure equal access to the child's right to be free from violence need to address these complexities.

Article 3 The Committee emphasises that the interpretation of a child's best interests cannot be used to justify practices, including corporal punishment, which conflict with a child's human dignity and right to physical integrity. Moreover, the Committee maintains that the best interests of the child in relation to Article 19 are best served by prevention of all forms of violence and the promotion of positive child-rearing through a national coordinating framework and adequate investment of resources in a child rights based and integrated child protection and support system 
(2011, para. 61). Articles 3 (2) and (3) require legislative and administrative measures to ensure such protection and care as is necessary for the child's well-being, and that state institutions, services, and facilities responsible for the care and protection of children conform with necessary standards and supervision.

Article 6 The child's inherent right to life, and to maximum survival and development, expresses positively, as a guiding principle, many of the goals set out in Article 19's promise of a life free from violence. Development is to be interpreted in the broadest possible sense, encompassing not simply protection from violence and exploitation but implementation measures which ensure the optimal physical, mental, spiritual, moral, psychological, and social development of the child (UN Committee on the Rights of the Child, 2011, para. 62). Articles 19 and 6 are also closely linked because of their common connection to the core human rights value of preserving the child's human dignity which underpins both articles (Lenzer, 2015, p. 278).

Article 12 The child's right to be heard and to have their opinions considered is critically important in all matters related to the application of Article 19, particularly in the identification, reporting, and investigation of child maltreatment, decisions regarding disruption of the family environment and the possibility of alternative care, and in health sector interventions addressing injuries or harms suffered by children. The Committee makes clear that children's views must be invited and given due weight as a mandatory step at every point in a child protection process, and that barriers to participation, particularly for marginalised children, must be addressed (2011, para. 63).

States Parties are invited to involve children in the development of prevention strategies and protective responses to violence in general, and in school (UN Committee on the Rights of the Child, 2003a, para. 63, 2016, para. 49). Initiatives and programmes aimed at strengthening children's own capacities to eliminate violence should be supported (UN Committee on the Rights of the Child, 2011, para. 63).

The Committee has made a strong case to respect child participation in child protection matters (2011, para. 63), and many encouraging best practices are emerging globally in this field. Article 12 includes the child's right to complaint mechanisms within institutions and the right to be informed of all institutional rules to which they may be subject and of existing procedures for redress (UNICEF, 2007, p. 566; UN Committee on the Rights of the Child, 2007b, para. 28).

\section{Articles Related or Linked to Article 19}

Article 5 proclaims the child's right to guidance and protection from their parents and family in the exercise of their rights, including the child's right to be protected from all forms of violence within and without the parental home. 
Article 9 guarantees the child's right to not be separated from their parents unless it is necessary and in their best interests, such as in a case of abuse or neglect by their parents.

Article 11 protects children from illicit transfer and non-return from other countries including international child abduction, which is a specific form of violence falling implicitly within the ambit of Article 19.

Article 16 concerns the child's right to privacy, the inviolability of their family life, and right to protection from unlawful attacks on their honour and reputation, such as bullying and cyber-bullying that will often infringe both Article 16 and Article 19.

Article 17 states the child's right to information and the States Parties' obligation to encourage guidelines for the protection of children from information and material injurious to their well-being. For example, latent and overt violence in the pornography industry points to the common obligations under Article 17 and 19.

Article 18 is the child's right to have both parents as primary caregivers and appropriate assistance to parents. Parents without appropriate state supports may be at greater risk of perpetrating violence towards their children hence the clear connection between Articles 18 and 19 of the Convention, as their juxtaposition suggests.

Article 20, the child's right to special protection, assistance, and alternative care if deprived of their family follows logically and sequentially from the guarantees in Article 19.

Article 21 proclaims the best interests of the child as the paramount consideration in relation to adoption and it must be applied judiciously where permanent removal of the child from a violent parent is the cause for the adoption placement.

Article 22 protects the rights of refugee children who are at increased risk of many forms of institutional violence and may be in great need of recovery supports for the violence from which they are fleeing.

Article 23 protects the rights of disabled children who are also at much greater risk of violence than their able-bodied peers.

Article 24, the child's right to the highest attainable standard of health, includes protections to combat child mortality, infectious diseases, harmful traditional practices, and environmental hazards.

Article 25, the right to periodic review of placement and treatment of children in care, includes those placed in care as a protection measure in response to their experience of violence at home.

Article 27 proclaims the child's right to an adequate standard of living, a key social determinant in preventing violence to children.

Article 28 (3) requires school discipline to be consistent with child's human dignity.

Article 32 requires protection from economic exploitation.

Article 33 requires protection from drug endangerment.

Article 34 requires protection from sexual exploitation.

Article 35 addresses the child's right to be protected from abduction, sale, or trafficking. 
Article 36 addresses protection from all other forms of exploitation.

Article 37 proclaims the child's right to be protected from torture or other cruel, inhuman, or degrading treatment or punishment.

Article 38 prohibits forced enrolment in armed conflict.

Article 39 provides the right to recovery and reintegration for child victims of neglect, exploitation, abuse, torture, cruel treatment, or armed conflict.

Article 40, the right to a separate system of youth criminal justice, which when read with Article 19 must be one that guards against institutional violence to children.

Optional Protocol on the involvement of children in armed conflict.

Optional Protocol on the sale of children, child prostitution and child pornography.

\section{Relevant Instruments}

International Covenant on Civil and Political Rights (1966), Articles 6, 7, 8, 9 and 10

UN Convention against Torture and Other Cruel, Inhuman or Degrading Treatment or Punishment (1984)

UN Standard Minimum Rules for the Administration of Juvenile Justice (Beijing Rules) (1985)

UN Rules for the Protection of Juveniles Deprived of their Liberty (Havana Rules) (1990)

UN Guidelines for the Prevention of Juvenile Delinquency (Riyadh Guidelines) (1990)

UN Guidelines on Justice in Matters involving Child Victims and Witnesses of Crime (2005)

UN Declaration on the Rights of Indigenous Peoples (2007), Articles 7(2), 17 (2) and 22(2)

UN Guidelines for the Alternative Care of Children (2009), paras 96-97

European Convention on Human Rights (1950), Articles 2, 3, 4 and 8

African Charter on the Rights and Welfare of the Child (1990)

Inter-American Convention on the International Return of Children (1989)

Inter-American Convention on International Traffic in Minors (1994)

\section{Attributes}

\section{Attribute One: Protection from All Forms of Violence}

No violence against children is justifiable, all violence against children is preventable (UN Committee on the Rights of the Child, 2011, para. 3). Article 19 leaves no 
room for any level of legalised violence to children. Frequency or severity of harm, or intent to harm, are not relevant factors in the application of this right.

Physical and mental violence include belittling, spurning, rejecting children or conveying that they are worthless, unwanted, or unloved, and also physical and psychological hazing or bullying. Neglect includes failing to protect children from preventable harm, and failure to provide the basic necessities, including lack of emotional supports, withholding of essential medical care or educational services, and abandonment. Prohibited violence outlined by the Committee includes corporal punishment in any setting, sexual abuse or exploitation, torture or degrading treatment, self-harm, violence between children, harmful practices (such as forced marriage and genital mutilation), violence in mass media and through social media, and institutional or systemic violations due to poor policy, poor evaluation, poor delivery, or underinvestment regarding child protection practices (UN Committee on the Elimination of Discrimination against Women and UN Committee on the Rights of the Child, 2014, paras. 10-30; UN Committee on the Rights of the Child, 2011, paras. 17-32, 2016, para. 49).

States Parties need to have comprehensive national coordinating frameworks in compliance with Article 4 to ensure that all forms of violence against children are adequately addressed and combatted, providing specific safeguards for children in vulnerable situations, such as children in residential care and children separated from family or kin.

\section{Attribute Two: Protection While in the Care of Parents, Legal Guardians, or Any Other Person}

The Committee has adopted a position whereby it assumes that all children under the age of 18 years are or should be in the care of someone. Accordingly, Article 19 applies to every child, despite the apparently restrictive language that protection applies while in the care of parents, legal guardian, or any other person (UN Committee on the Rights of the Child, 2011, para. 33). Article 19 extends to arrangements where the state may be the caregiver when parents cannot fulfil this responsibility, and to other caregivers including legal guardians or any other person who has care of the child: foster parents, adoptive parents, extended family and community members, school and day-care personnel, caregivers employed by parents (e.g. coaches and youth group supervisors), and institutional personnel (such as residential, health care and juvenile justice staff) (UN Committee on the Rights of the Child, 2011, para. 33).

Article 19 also applies to children without a primary or proxy caregiver, such as children in street situations and unaccompanied minors (UN Committee on the Rights of the Child, 2011, para. 35). Children may be subject to violence by primary or proxy caregivers, and others against whom the caregiver is expected to provide protection (for example, neighbours, peers, and strangers), as well as by state actors 
who misuse their authority in various settings. All these situations are captured by Article 19, which is not limited to violence perpetrated by caregivers in a personal context only (UN Committee on the Rights of the Child, 2011, para. 36).

\section{Attribute Three: All Appropriate Measures}

States Parties must not only address all forms of violence, but Article 19 (1) requires that they do so through all appropriate measures: 'legislative, administrative, social and educational.' These include the general measures of implementation of child rights set out by the Committee in its General Comment no. 5 (2003b). Moreover, the Committee calls for 'an integrated, cohesive, interdisciplinary and coordinated system,' including all the measures enumerated in Article 19 (1) and all the interventions identified in Article 19 (2), for all children inclusively (2011, para. 39). For instance, 'legislative measures,' including budgets, means both laws and sub-regulatory instruments of enforcement at national, sub-national, and local levels. General Comment no. 13 elaborates a broad and comprehensive range of measures that must be undertaken as the national, regional, and local levels including obligations to (UN Committee on the Rights of the Child, 2011, paras. 41-44):

- ratify relevant instruments and international and regional instruments

- review and lift reservations and declarations

- strengthen cooperation with treaty bodies

- ensure conformity with all domestic legislation

- provide effective redress mechanisms for rights violations domestically

- establish social programmes to support positive parenting

- establish a national institution for children's rights, as well as sub-national independent human rights institutions with specific child rights mandates

\section{Attribute Four: Effective Identification, Reporting, Investigation, and Treatment of Harm}

Article 19 (2) completes the call for comprehensiveness in relation to measures to combat all violence by enumerating the range of interventions to be addressed. States Parties must take measures to intervene effectively in relation to proactive prevention and prohibition of all forms of violence and also with respect to its identification, reporting, referral, investigation, treatment, and follow-up, including appropriate processes for judicial intervention (UN Committee on the Rights of the Child, 2011, paras. 45-57).

The Committee has emphasised that child protection must begin with proactive measures to prevent and prohibit all forms of violence (2011, para. 46). In this regard, it has identified the importance of awareness raising and training as a key 
preventive strategy, along with the adoption of national policy statements on violence against children and comprehensive studies on the extent, nature, causes and impact of such violence (2001, para. 723). Children must be provided with as many opportunities as possible to signal emerging problems before they reach a state of crisis, and for adults to recognise and effectively act on such problems in a manner that gives due weight to the child's views (UN Committee on the Rights of the Child, 2011, paras. 48, 50). The importance of child participation at every stage of the child protection system must be recognised.

\section{References}

Krug, E. G., Dahlberg, L. L., Mercy, J. A., Zwi, A. B., \& Lozano, R. (Eds.). (2002). World report on violence and health. World Health Organization. Accessed November 21, 2020, from https:// www.who.int/violence_injury_prevention/violence/world_report/chapters/en/

Lenzer, G. (2015). Violence against children. In Routledge international handbook of children's rights studies. Routledge.

Machel, G. (1996). Impact of armed conflict on children: Note by the Secretary-General, A/51/306. UN. Accessed November 21, 2020, from http://digitallibrary.un.org/record/223213

Pinheiro, P. S. de M. S. (2006). Report of the independent expert for the United Nations Study on violence against children, A/61/299. UN. Accessed November 12, 2020, from http:// digitallibrary.un.org/record/584299

Ravnbøl, C. I. (2009). Intersectional discrimination against children: Discrimination against Romani children and anti-discrimination measures to address child trafficking. Innocenti Working Papers, 2009(11). https://doi.org/10.18356/7e89512e-en

UN Committee on the Elimination of Discrimination against Women \& UN Committee on the Rights of the Child. (2014). Joint general recommendation no. 31 of the committee on the elimination of discrimination against women/general comment no. 18 of the committee on the rights of the child on harmful practices, CEDAW/C/GC/31, CRC/C/GC/18. UN. Accessed November 13, 2020, from http://digitallibrary.un.org/record/807256

UN Committee on the Rights of the Child. (2001). Day of general discussion: Violence against children within the family and in school. UN. Accessed November 22, 2020, from https://www. ohchr.org/EN/HRBodies/CRC/Pages/DiscussionDays.aspx

UN Committee on the Rights of the Child. (2003a). General comment no. 3 (2003) HIV/AIDS and the rights of the child, March 17, 2003, CRC/GC/2003/3. Accessed October 12, 2020, from https://digitallibrary.un.org/record/501529? $\mathrm{ln}=\mathrm{en}$

UN Committee on the Rights of the Child. (2003b). General comment no. 5 (2003) General measures of implementation of the convention on the rights of the child (arts. 4, 42 and 44, para. 6), November 27, 2003, CRC/GC/2003/5. Accessed October 12, 2020, from https:// digitallibrary.un.org/record/513415? $\mathrm{ln}=\mathrm{en}$

UN Committee on the Rights of the Child. (2005). General comment no. 6 (2005) treatment of unaccompanied and separated children outside their country of origin, September 1, 2005, $C R C / G C / 2005 / 6$. Accessed October 12, 2020, from https://digitallibrary.un.org/record/566055? $\ln =\mathrm{en}$

UN Committee on the Rights of the Child. (2006). General Comment No. 7 (2005) Implementing child rights in early childhood, September 20, 2006, CRC/C/GC/7/Rev.1. Accessed October 12, 2020, from https://digitallibrary.un.org/record/584854? $\mathrm{ln}=\mathrm{en}$

UN Committee on the Rights of the Child. (2007a). General Comment No. 9 (2006) The rights of children with disabilities, November 13, 2007, CRC/C/GC/9. Accessed October 12, 2020, from https://digitallibrary.un.org/record/593891? $\mathrm{ln}=\mathrm{en}$ 
UN Committee on the Rights of the Child. (2007b). General Comment No. 10 (2007) Children's rights in juvenile justice, April 25, 2007, CRC/C/GC/10. Accessed October 12, 2020, https:// digitallibrary.un.org/record/599395? $\mathrm{ln}=\mathrm{en}$

UN Committee on the Rights of the Child. (2009). General comment No. 11 (2009), Indigenous children and their rights under the Convention, February 12, 2009, CRC/C/GC/11. Accessed October 24, 2020, from https://digitallibrary.un.org/record/648790? $1 \mathrm{n}=\mathrm{en}$

UN Committee on the Rights of the Child. (2011). General comment No. 13 (2011) The right of the child to freedom from all forms of violence, April 18, 2011, CRC/C/GC/13. Accessed October 12, 2020, from https://digitallibrary.un.org/record/711722? $\ln =\mathrm{en}$

UN Committee on the Rights of the Child. (2016). General comment no. 20 (2016) on the implementation of the rights of the child during adolescence, December 6, 2016, CRC/C/GC/ 20. Accessed October 12, 2020, from https://digitallibrary.un.org/record/855544? $1 \mathrm{n}=\mathrm{en}$

UN Special Representative of the Secretary-General on Violence Against Children. (2015). Toward a world free from violence: Global survey on violence against children. UN. Accessed November 21, 2020, from http://digitallibrary.un.org/record/3846479

UNICEF. (2007). Implementation handbook for the convention on the rights of the child (3rd ed.). UNICEF. Accessed September 21, 2020, from https://digitallibrary.un.org/record/620060? $\ln =$ en

Vučković-Šahović, N., Doek, J. E., \& Zermatten, J. (2012). The rights of the child in international law: Rights of the child in a nutshell and in context: All about children's rights. Stämpfli.

Open Access This chapter is licensed under the terms of the Creative Commons Attribution 4.0 International License (http://creativecommons.org/licenses/by/4.0/), which permits use, sharing, adaptation, distribution and reproduction in any medium or format, as long as you give appropriate credit to the original author(s) and the source, provide a link to the Creative Commons license and indicate if changes were made.

The images or other third party material in this chapter are included in the chapter's Creative Commons license, unless indicated otherwise in a credit line to the material. If material is not included in the chapter's Creative Commons license and your intended use is not permitted by statutory regulation or exceeds the permitted use, you will need to obtain permission directly from the copyright holder.

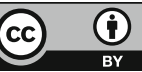

